\title{
Pruning to control tree size, flowering and production of litchi
}

\author{
Trevor Olesen $^{\mathrm{a}, \mathrm{b}}$, Christopher M. Menzel ${ }^{\mathrm{c}, *}$, Cameron A. McConchie $^{\mathrm{d}}$, Neil Wiltshire ${ }^{\mathrm{e}}$ \\ a Department of Primary Industries, Wollongbar, NSW, Australia \\ ${ }^{\mathrm{b}}$ University of New England, Armidale, NSW, Australia \\ c Department of Agriculture, Fisheries and Forestry, Nambour, Qld., Australia \\ ${ }^{\mathrm{d}}$ Department of Resources, Darwin, NT, Australia \\ e Department of Agriculture, Fisheries and Forestry, South Johnstone, Qld., Australia
}

\section{A R T I C L E I N F O}

\section{Article history:}

Received 5 December 2012

Received in revised form 11 March 2013

Accepted 12 March 2013

\section{Keywords:}

Climate

Flowering

Litchi chinensis

Pruning

Vegetative growth

Yield

\begin{abstract}
A B S T R A C T
We investigated the effect of hedging on the yield of 'Kwai May Pink' litchi (Litchi chinensis Sonn.) trees over 4 years at three sites in eastern Australia. Individual trees in these orchards were pruned at various times to remove $0.5-1.0 \mathrm{~m}$ of the terminal branches. At Brooklet in northern New South Wales, at the southern end of the commercial range of the crop, the optimum time of pruning appeared to be in earlyto mid-February, but this was before the previous crop was harvested. Trees hedged in early March had virtually no crop since most of the branches did not complete a flush of growth before the normal time of floral initiation in winter. In Bundaberg in southern Queensland, this was not an issue, and good yields followed hedging in late February or early March in 3 out of 3 years. In Mareeba in northern Queensland at the northern end of the commercial range, hedging in mid-March was highly variable, with good yields in 1 out of 4 years and poor yields in 3 out of 4 years. The optimum time of pruning appeared to be in early January or early March in this area, which would allow the completion of two or one growth flushes before winter. There is the added problem in this environment that the trees may not flower every year because the warmer conditions provide only a short window for floral initiation. Trees at Bundaberg and Mareeba hedged in May or June just before the normal time of floral initiation flowered but cropped poorly compared with control trees. The results of this study confirm the strong relationship between flowering and shoot development in litchi. They also support the idea that the developing fruit are dependent on current photosynthates produced by the leaves behind the inflorescences. Suggestions are provided on options for pruning litchi trees growing in different environments, including warm tropical areas, warm subtropical areas, and cool subtropical areas.
\end{abstract}

Crown Copyright @ 2013 Published by Elsevier B.V. All rights reserved.

\section{Introduction}

Litchi (Litchi chinensis Sonn.) originated in southern China and northern VietNam, but has now spread to most countries that experience a subtropical climate (Menzel and Waite, 2005). The species is most important in China, India, VietNam and Thailand, with significant plantings also in Australia, South Africa, the United States and South America. One of the major factors affecting the production of this subtropical fruit in many countries is low yields. The trees may fail to flower some seasons or fail to set and carry a reasonable crop (Menzel, 2001). The lack of flowering is usually related to the weather or the timing of shoot growth during the cooler months of the year.

\footnotetext{
* Corresponding author at: Department of Agriculture, Fisheries and Forestry, PO Box 5083, SCMC, Nambour, Qld. 4560, Australia. Tel.: +61 7 54535945; fax: +61 754535901 .

E-mail address: chris.menzel@daff.qld.gov.au (C.M. Menzel).
}

Olesen et al. (2002) showed that the cycle of shoot development affected flowering in litchi. This was the first demonstration of such a response in a recurrent flushing tree species. The same effect has since been shown for avocado, Persea americana (Olesen, 2005), macadamia, Macadamia integrifolia (Olesen, 2005; Wilkie et al., 2010), and mango, Mangifera indica (Davenport, 2007; Wilkie et al., 2008b; Ramírez and Davenport, 2010). It is likely that this response will apply to other evergreen, recurrent flushing trees (Olesen, 2005; Wilkie et al., 2008a). In these species, the success of flowering in a given year is related to the timing of shoot development before the normal period of floral initiation. The shoots of these trees may grow repeatedly during the growing season provided conditions are favourable for growth (Borchert, 1969, 1991).

In litchi and mango, temperature controls floral induction, with the direction of shoot development as an inflorescence or a vegetative shoot with leaves determined when the emerging buds are only a few millimetres long (Batten and McConchie, 1995; Olesen et al., 2002). In 'Salathiel' litchi, if the new buds were exposed to cool temperatures when they were 0 to $4 \mathrm{~mm}$ long they produced a mixture 
of pure inflorescences, leafy inflorescences or leafy shoots, whereas if the new buds were exposed to cool temperatures when they were longer than $4 \mathrm{~mm}$ long they produced only leafy shoots (Batten and McConchie, 1995). Litchi, mango and the other crops generally do not flower directly in response to water deficits (Chaikiattiyos et al., 1994).

Evergreen subtropical crops such as avocado, litchi, macadamia and mango are often hedged or pruned to control the size of the trees (Menzel et al., 2000; Wilkie et al., 2009). This helps reduce the cost of harvesting, which often accounts for more than half the expense of growing the crops. Pruning improves the distribution of light through the canopy and promotes the growth of groundcovers used to combat soil erosion. The distribution of chemical sprays to control pests and diseases is also generally better in small trees with open canopies that have been pruned.

Hedging removes the apical bud, stimulates the growth of the axillary buds and resets the flushing cycle in these tree crops. So the timing of hedging is important in order to maximise flowering and fruit production (Wilkie et al., 2010). For most of the subtropical species, pruning is aimed at producing new shoots during cool weather in winter when they are most likely to flower.

We examined the effect of time of hedging on the production of litchi trees at Mareeba in northern Queensland, at Bundaberg in southern Queensland and at Brooklet in northern New South Wales in eastern Australia. The first site was at the northern end of commercial production of the crop, while the two other sites were at the southern end of commercial production (Diczbalis et al., 2010). Total production of litchi in Australia is about 3500 t. About $60 \%$ of the crop is produced in central and northern Queensland, 35\% of the crop is produced in southern Queensland, and about $5 \%$ of the crop is produced in northern New South Wales.

In our experiments, the trees were hedged at various times from February to June, and the impact on fruit yield recorded. The results of the research were used to identify the best times to prune litchi trees in the different growing areas in Australia. The approaches developed in this research could be used to investigate optimum times of pruning in other countries and growing environments.

\section{Materials and methods}

\subsection{Sites and tree agronomy}

The work was conducted on three commercial 'Kwai May Pink' litchi orchards in eastern Australia. One property was at Brooklet in northern New South Wales (lat. $29^{\circ} \mathrm{S}$ and long. $153^{\circ} \mathrm{E}$ ), one was at Bundaberg in southern Queensland (lat. $25^{\circ} \mathrm{S}$ and long. $152^{\circ} \mathrm{E}$ ), and one was at Mareeba in northern Queensland (lat. $17^{\circ} \mathrm{S}$ and long. $145^{\circ} \mathrm{E}$ ). The trees in the orchards were grown as commercial crops with respect to fertiliser applications, irrigation and pest control (Menzel et al., 2002). The trees used at Brooklet were 10-years-old and about $5.0 \mathrm{~m}$ high in 1995. The trees used at Bundaberg from 1995 to 1997 were 6- to 10-years-old and about 3.5-4.0 m high. The trees used at Mareeba from 1995 to 1998 were 8-11-years-old and about 4.0-4.5 m high. The distance between the rows was $8 \mathrm{~m}$ at Brooklet, $6 \mathrm{~m}$ at Bundaberg, and $10 \mathrm{~m}$ at Mareeba. The distance between the trees along the rows was $4 \mathrm{~m}$ at all three sites. 'Kwai May Pink' is the dominant litchi cultivar in Australia and represents about $50 \%$ of commercial production (Diczbalis et al., 2010). It has wide environmental adaptation, and crops well in most growing areas. The fruit of this cultivar are normally available in mid- to late December in northern Queensland, in early- to mid-January in southern Queensland, and in mid- to late February in northern New South Wales.

\subsection{Experimental treatments and design}

The same experimental set-up was used to evaluate the optimum time of pruning for each year and at each location. Eight to twenty trees were selected in each orchard and randomly allocated into two treatments: one group was pruned or hedged while the other group was left unpruned and acted as the control plots. Pruning involved the removal of at least the most recent leafy shoot flush from all the branches on the canopy, using a petrol-driven hand-hedger. Typically, this involved pruning up to $0.5 \mathrm{~m}$ from each branch. The only exception to this practice was at Bundaberg in 1997 when the pruning was more severe, with the removal of up to $1 \mathrm{~m}$ from the terminal branches. The trees at Brooklet were pruned on 2 March in 1995. The trees at Bundaberg were pruned on 8 March or on 16 May in 1995; on 26 February in 1996; or on 3 February, 26 February or on 26 March in 1997. The trees at Mareeba were pruned on 22 March or on 15 June in 1995; on 18 March in 1996; on 20 March in 1997; or on 18 March in 1998.

\subsection{Data collection}

Yields were recorded in all experiments, as the number of fruit per tree at commercial harvest. The only exception to this was at Bundaberg in 1995, where the yields were recorded as fruit fresh weight per tree.

Additional data were collected for some of the experiments at the different sites. For the experiments at Brooklet and Bundaberg in 1995, information was collected on shoot growth over time in selected branches. Eight branches in the upper canopy of each tree were tagged, and the length of the new shoots monitored about every fortnight from March to December. The numbers of primary, secondary and tertiary branches greater than $10 \mathrm{~mm}$ in length were also recorded on the floral flushes or inflorescences.

Canopy heights, widths and breadths were measured in each of the control and pruned trees at Bundaberg in 1996 and 1997, and at Mareeba in 1998. The canopy surface area of each tree was estimated, assuming that each canopy was the shape of an irregular semi-ellipsoid. There is no analytical solution to the estimate, so the estimate was made using a net of triangles (Lang, 1991). These data were then used to calculate relative yield as the number of fruit per unit canopy surface area.

\subsection{Data analyses}

The data on yield as number or weight of ripe fruit per tree were analysed by $t$-tests to compare the productivity of the pruned and control plots for each individual experiment at each site (Ireland, 2010). Similar analyses were conducted to assess the effect of pruning on canopy surface area and fruit yield per canopy surface area (relative yield) at Bundaberg in 1996 and 1997; and on the number of branches per tree, incidence of flowering, canopy surface area and fruit yield per canopy surface area at Mareeba in 1998.

The data on the length of the main axis of the inflorescence and on the branching of the inflorescences at Brooklet and Bundaberg in 1995 were analysed by the $t$-test (Ireland, 2010). The data on the growth of the shoots over time at Brooklet and Bundaberg in 1995 were analysed using a modified sine function (Olesen et al., 2002). The regressions were fitted using the Marquardt-Levenberg algorithm in SigmaPlot (version 11; Systat, Chicago).

\section{Results}

\subsection{Brooklet in 1995}

The control trees initiated new shoots in April (Fig. 1A). These were floral and continued to elongate until anthesis in October. The 
Table 1

Effect of pruning on the numbers of primary, secondary and tertiary branches greater than $10 \mathrm{~mm}$ in length per inflorescence on 'Kwai May Pink' litchi trees growing at Brooklet in northern New South Wales and at Bundaberg in southern Queensland in Australia in 1995. Data were recorded for the longest of 8 shoots per tree, with 5 trees per treatment. Means ( \pm SEs) within a column followed by different letters are significantly $(P<0.05)$ different using the $t$-test. The hedged trees at Brooklet did not flower.

\begin{tabular}{llll}
\hline $\begin{array}{l}\text { Site and } \\
\text { treatment }\end{array}$ & $\begin{array}{l}\text { No. of } 1^{\circ} \\
\text { branches }\end{array}$ & $\begin{array}{l}\text { No. of } 2^{\circ} \\
\text { branches }\end{array}$ & $\begin{array}{l}\text { No. of } 3^{\circ} \\
\text { branches }\end{array}$ \\
\hline $\begin{array}{l}\text { Brooklet } \\
\text { Control }\end{array}$ & $\begin{array}{l}9.8 \pm 1.2^{\mathrm{ab}} \\
\text { n.a. }\end{array}$ & $\begin{array}{l}15.0 \pm 2.9^{\mathrm{c}} \\
\text { n.a. }\end{array}$ & $\begin{array}{l}1.0 \pm 0.4^{\mathrm{e}} \\
\text { n.a. }\end{array}$ \\
$\begin{array}{l}\text { Hedged } \\
\text { Bundaberg }\end{array}$ & & \\
$\begin{array}{l}\text { Control } \\
\text { Hedged }\end{array}$ & $\begin{array}{l}11.2 \pm 0.4^{\mathrm{a}} \\
7.4 \pm 0.6^{\mathrm{b}}\end{array}$ & $\begin{array}{l}23.2 \pm 2.9^{\mathrm{c}} \\
6.2 \pm 2.2^{\mathrm{d}}\end{array}$ & $\begin{array}{l}1.0 \pm 0.6^{\mathrm{e}} \\
0^{\mathrm{e}}\end{array}$ \\
\hline
\end{tabular}

inflorescences were highly branched (Table 1 ), and the trees had moderate yields, with a mean of 828 fruit per tree (Table 2). The trees hedged on 2 March produced new shoots shortly afterwards, well ahead of the controls, and all the flushes were leafy or vegetative (Fig. 1A). The subsequent flushes produced in September were predominantly leafy, with only a few inflorescences on 2 out of the 5 trees. There were 5 fruit on 1 tree, and no fruit on the other 4 trees.

\subsection{Bundaberg in 1995}

The control trees in the "March" experiment initiated inflorescences in May, with the flowers opening in late September (Fig. 1B). The trees hedged on 8 March produced leafy shoots shortly afterwards, well ahead of the controls. There were subsequent floral flushes on the hedged trees in August, with the flowers on these trees opening in late October. The maximum lengths of the inflorescences of the control and hedged trees were similar $(t$-test, $P>0.05$, Fig. 1B), but the inflorescences on the control trees were more branched than those on the hedged trees (Table 1). The yields of the two groups of trees were similar (Table 2), with harvesting about one week later in the hedged trees. Pruning maintained the height of the canopy.

In the "May" experiment, the trees flowered after pruning on 16 May. The control trees also produced inflorescences in June. The yields of the control trees were 3.5 times greater than the yields of the hedged trees (Table 2).
Table 3

Effect of pruning on canopy surface area and yield per canopy surface area of 'Kwai May Pink' litchi trees growing at Bundaberg, Australia in 1997. Data are the means $( \pm$ SEs) of 9 or 10 trees per treatment. The results of $t$-tests are shown to indicate if the difference between the performance of the control and hedged trees within a row was significant $(P<0.05)$.

\begin{tabular}{llrr}
\hline Date of hedging & $\begin{array}{l}\text { Result of } t \text {-test } \\
(P<0.05)\end{array}$ & Control & Hedged \\
\hline & Canopy surface area $\left(\mathrm{m}^{2}\right.$ per tree $)$ & \\
3 February & Significant & $32.7 \pm 1.8$ & $24.4 \pm 1.3$ \\
26 February & Significant & $37.7 \pm 1.9$ & $28.3 \pm 0.8$ \\
26 March & Significant & $39.6 \pm 2.5$ & $28.7 \pm 1.3$ \\
& No. of fruit per canopy surface area of tree $\left(\mathrm{m}^{2}\right)$ \\
3 February & Significant & $35.5 \pm 5.2$ & $17.7 \pm 3.2$ \\
26 February & Not significant & $48.7 \pm 3.8$ & $43.9 \pm 2.0$ \\
26 March & Significant & $44.9 \pm 2.4$ & $18.7 \pm 6.5$ \\
\hline
\end{tabular}

\subsection{Bundaberg in 1996 and 1997}

In 1996, the trees hedged on 26 February behaved similarly to those hedged on 8 March in 1995, producing a leafy and then a floral flush. Both the control and hedged trees flowered well and had similar yields (Table 2). The canopy surface area of the hedged trees $\left(33.7 \pm 4.0 \mathrm{~m}^{2}\right)$ (mean \pm standard error) was slightly less than that of the control trees $\left(39.7 \pm 5.1 \mathrm{~m}^{2}\right)(t$-test, $P>0.05)$. The relative yield of the hedged trees $\left(17.7 \pm 3.1\right.$ fruit per $\left.\mathrm{m}^{2}\right)$ was similar to that of the control trees $\left(20.7 \pm 1.2\right.$ fruit per $\left.\mathrm{m}^{2}\right)(t$-test, $P>0.05)$.

In 1997, the trees hedged on 26 February behaved similarly to those hedged on 8 March in 1995 and those hedged on 26 February in 1996, producing a leafy and then a floral flush. At harvest, the control trees produced more fruit per tree than the hedged trees (Table 2). However, yields per canopy surface area were similar (Table 3), reflecting the smaller canopies of the hedged trees compared with those of the control trees (Table 3). For the trees hedged earlier on 3 February or later on 26 March, the absolute and relative yields were lower than those of the control trees (Tables 2 and 3 ).

\subsection{Mareeba in 1995, 1996, 1997 and 1998}

The yields of the trees hedged from 18 to 22 March in 1995 , 1996,1997 or 1998 were highly variable (Table 2 ), and similar to the control trees in 1995 but less in subsequent years. The relative yield of the hedged trees in 1998, the only year in which relative yield was measured, was lower than that of the control trees (Table 4). The lower absolute and relative yields in 1998 corresponded with a lower proportion of the branches in the trees flowering (Table 4).

Table 2

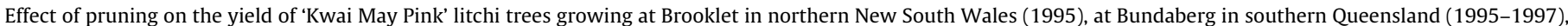

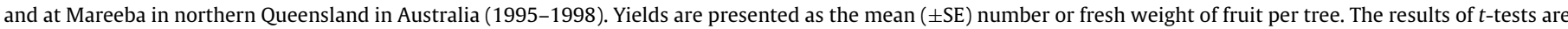
shown to indicate if the difference in yield between the control and hedged trees within a row was significant $(P<0.05)$.

\begin{tabular}{|c|c|c|c|c|c|}
\hline \multirow[t]{2}{*}{ Site and year } & \multirow[t]{2}{*}{ Date of hedging } & \multirow[t]{2}{*}{ Number of trees per treatment } & \multirow[t]{2}{*}{ Result of $t$-test $(P<0.05)$} & \multicolumn{2}{|c|}{$\begin{array}{l}\text { Yield (number of fruit or fresh weight } \\
\text { of fruit per tree) }\end{array}$} \\
\hline & & & & Control & Hedged \\
\hline \multicolumn{6}{|l|}{ Brooklet } \\
\hline 1995 & 2 March & 5 & Significant & $828 \pm 120$ fruit & $1 \pm 1$ fruit \\
\hline \multicolumn{6}{|l|}{ Bundaberg } \\
\hline 1995 & 8 March & 5 & Not significant & $19.5 \pm 3.4 \mathrm{~kg}$ & $15.8 \pm 3.4 \mathrm{~kg}$ \\
\hline 1995 & 16 May & 5 & Significant & $24.2 \pm 1.9 \mathrm{~kg}$ & $6.9 \pm 4.2 \mathrm{~kg}$ \\
\hline 1996 & 26 February & 5 & Not significant & $828 \pm 129$ fruit & $625 \pm 182$ fruit \\
\hline 1997 & 3 February & 10 & Significant & $1165 \pm 182$ fruit & $457 \pm 93$ fruit \\
\hline 1997 & 26 February & 10 & Significant & $1827 \pm 166$ fruit & $1233 \pm 51$ fruit \\
\hline 1997 & 26 March & 9 & Significant & $1782 \pm 158$ fruit & $524 \pm 193$ fruit \\
\hline \multicolumn{6}{|l|}{ Mareeba } \\
\hline 1995 & 22 March & 5 & Not significant & $2354 \pm 26$ fruit & $2222 \pm 269$ fruit \\
\hline 1995 & 15 June & 4 & Not significant & $1613 \pm 521$ fruit & $694 \pm 317$ fruit \\
\hline 1996 & 18 March & 5 & Significant & $2616 \pm 57$ fruit & $1709 \pm 265$ fruit \\
\hline 1997 & 20 March & 5 & Significant & $2380 \pm 133$ fruit & 0 fruit \\
\hline 1998 & 18 March & 5 & Significant & $3237 \pm 296$ fruit & $1189 \pm 426$ fruit \\
\hline
\end{tabular}




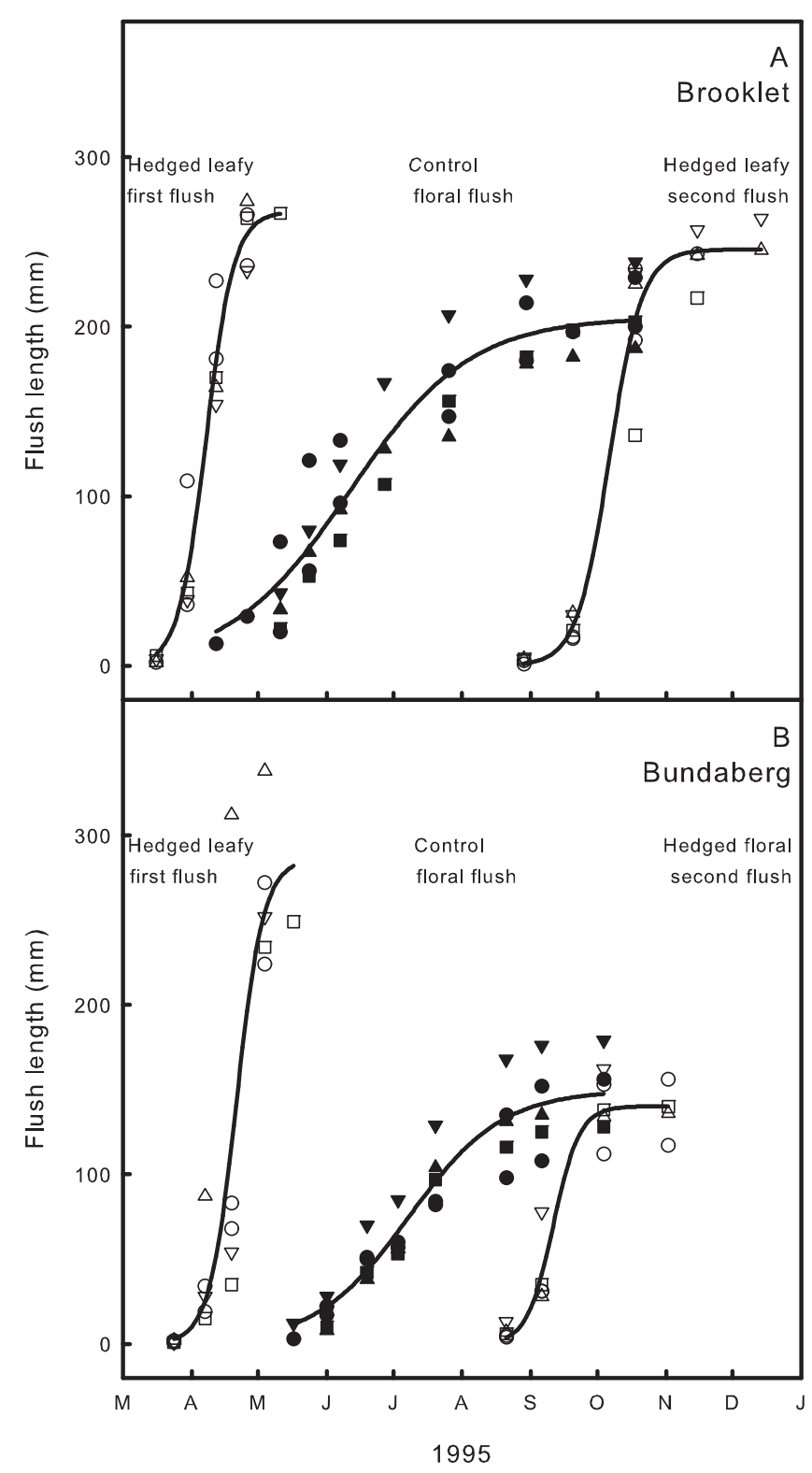

Fig. 1. Effect of pruning on shoot growth in 'Kwai May Pink' litchi trees growing at Brooklet in northern New South Wales (A), and at Bundaberg in southern Queensland in Australia (B) in 1995. The trees at Brooklet were pruned on 2 March and the trees at Bundaberg were pruned on 8 March. The data points are of the longest shoots to develop across 8 tagged branches for each of 5 individual trees per treatment, with the response over time shown as a modified sine function. The yields of the trees are shown in Table 2.

\section{Table 4}

Effect of pruning on canopy dynamics in 'Kwai May Pink' litchi trees growing at Mareeba, Australia in 1998. The trees were hedged on 18 March. Data are the means ( \pm SEs) of 5 trees per treatment. The results of $t$-tests are shown to indicate if the difference between the performance of the control and hedged trees within a row was significant $(P<0.05)$.

\begin{tabular}{|c|c|c|c|}
\hline Parameter & $\begin{array}{l}\text { Result of } t \text {-test } \\
(P<0.05)\end{array}$ & Control & Hedged \\
\hline No. of branches per tree & Not significant & $1047 \pm 80$ & $885 \pm 80$ \\
\hline No. of floral branches per tree & Significant & $930 \pm 97$ & $591 \pm 100$ \\
\hline No. of leafy branches per tree & Significant & $117 \pm 30$ & $293 \pm 54$ \\
\hline $\begin{array}{l}\text { Percent of branches that were } \\
\text { floral }\end{array}$ & Significant & $88 \pm 4$ & $66 \pm 8$ \\
\hline $\begin{array}{l}\text { Canopy surface area }\left(\mathrm{m}^{2} \text { per }\right. \\
\text { tree) }\end{array}$ & Not significant & $45.7 \pm 2.3$ & $38.7 \pm 2.3$ \\
\hline $\begin{array}{l}\text { No. of fruit per canopy surface } \\
\text { area of tree }\left(\mathrm{m}^{2}\right)\end{array}$ & Significant & $71.3 \pm 7.3$ & $32.9 \pm 12.1$ \\
\hline
\end{tabular}

In 1995, there was an additional experiment, with a group of trees hedged on 15 June, just before the normal period of flower initiation. These trees flowered after pruning, about at the same rate as the control trees. At harvest, the control trees had 2.3 times the number of fruit of the hedged trees (Table 2), although the difference was not significant ( $t$-test, $P>0.05$ ), possibly due to there being only 4 trees in each group and large variability across the trees in a treatment.

\section{Discussion}

Hedging changed the pattern of shoot development in the litchi trees, with new shoots developing soon after the branches were pruned. The impact of the treatment on flowering and fruit yield was influenced by the time of pruning, with variations in the optimum time depending on the growing area. Pruning maintained the height of the canopy, provided the trees flowered after hedging. In general, our results are in agreement with those reported by Hieke (2000) and Olesen et al. (2002).

There have been several earlier studies on the response of litchi trees to pruning, with experiments conducted in Florida (Young, 1977; Campbell, 1994), Taiwan (Yen and Tien, 1985), Israel (Goren, 1990; Stern et al., 2005) and Australia (Menzel et al., 1996). An analysis of this research indicates a mixed response to pruning or hedging, with many cases of lower yields in the pruned trees compared with the yields in the control trees.

\subsection{The response to hedging in Brooklet}

In Brooklet, hedging in early March in 1995 resulted in poor flowering. The hedged trees produced a leafy flush soon after pruning and a second one in September. Olesen et al. (2002) also found poor flowering on flushes commencing in late August or early September at nearby Alstonville. These results, in conjunction with modelling conducted by Menzel et al. (2000), demonstrate that hedging in early March in northern New South Wales is too late to renew the canopy to produce a leafy and then a floral flush in most years, notwithstanding the long winters in this area. This poses difficulties for canopy management in this cool subtropical environment because the fruit of 'Kwai May Pink' often do not mature before the end of February. The optimum time for pruning of this cultivar in this environment is probably from early- to mid-February.

Efforts to control the size of 'Kwai May Pink' trees at Brooklet are likely to come at the expense of cropping, at least for the first season after pruning. There are few early season cultivars such as Tai So and Bengal that can be grown in northern New South Wales, but their fruit have large seeds and poor eating quality compared with the fruit of Kwai May Pink. The other possibility is to prune part of the tree each year. The pruned sections of the tree would support the development of the crop in the non-pruned sections (Hieke et al., 2002a).

\subsection{The response to hedging in Bundaberg}

There was mixed response to hedging at Bundaberg, but the performance of the trees was generally consistent with the ideas developed by Batten and McConchie (1995) and Olesen et al. (2002). Trees that produced new shoots in winter typically flowered and cropped. The yields of the pruned trees were lower than the yields of the control trees in 4 out of 6 cases, and similar in 2 out of 6 cases. This was expected, since the pruned trees were usually smaller than the control trees.

To separate the effect of shoot development from the effect of the size of the tree, the yield data in 1996 and 1997 were expressed in absolute (yield per tree) and relative terms (yield per unit canopy 
surface area). In 1996, absolute and relative yields were similar in the pruned and control trees, when the trees were hedged in late February. In 1997, absolute yields were lower in all the trees that were pruned compared with the yields of the respective controls, whereas relative yields were lower only when the trees were pruned in early February or in late March. Relative yields of the hedged and control plots were similar when the trees were pruned in late February or in early March.

The experiment in 1995 showed that trees pruned in early March had similar yields as the control trees when the yield data were expressed in absolute terms. This experiment included a more detailed assessment of the impact of pruning on the pattern of shoot development. The control trees initiated inflorescences in May, while the hedged trees initiated leafy shoots in April and inflorescences in August (Fig. 1B). It is apparent that the trees could produce inflorescences from May to August at this site in 1995. There is a moderately long and reliably cool winter for floral induction in southern Queensland as found by Olesen et al. (2002).

In 1995, we included an experiment where the trees were pruned in mid-May just before the normal time of floral initiation. Both the control and hedged trees flowered, however, the yields of the control trees were 3.5 times greater than the yields of the hedged trees. Differences in the size of the trees after pruning did not completely explain the differences in yields between the two groups of trees. There are several reports that suggest that developing litchi fruit are dependent on current photosynthates produced by the new leaves below the inflorescences (Yuan and Huang, 1988; Roe et al., 1997; Hieke et al., 2002b; Bikash et al., 2011). Similar data were also reported in macadamia by Olesen et al. (2008). The branches that were pruned would have had fewer leaves per shoot than the branches that were left intact.

Overall, the best response to hedging occurred when the trees at Bundaberg were pruned in late February or early March. Hedging is more reliable at Bundaberg that at Brooklet, possibly due to the slightly earlier harvest in southern Queensland, and the slightly warmer conditions after harvest. Both areas have a reasonably long cool period in winter suitable for floral induction in this species.

\subsection{The response to hedging in Mareeba}

Five experiments were conducted at Mareeba to assess the effect of pruning on growth, flowering and yield in the litchi trees. There were four experiments examining the response to pruning in March, and a single experiment examining the response to pruning in June. The last experiment was similar to the work conducted at Bundaberg where the trees were pruned in May around the time of floral initiation.

When the trees were hedged in March, the pruned trees had lower yields than the control trees in 3 out of 4 cases, and similar yields in 1 out of 4 cases. In 1998, other data were collected to examine the response to pruning in this environment. This analysis showed that hedged trees had only a third of the yield of control trees on an absolute basis, and about half the yield on a relative basis when the data were expressed as the number of fruit per canopy surface area of the trees. So the lower yields of the pruned trees did not just reflect their smaller size. The data on flowering also indicates that the hedged trees had a lower proportion of their branches flowering. This analysis indicates that a major response to pruning in winter includes an effect on the initiation of inflorescences.

Overall, hedging in March in Mareeba gave a mixed response, from good yields to no yield at all. This might have been because of the timing of pruning and the short winters in northern Queensland (Olesen et al., 2002) causing poor flowering in years like 1998 and no flowering in years like 1997. Mareeba differs from Brooklet and Bundaberg in that there is sufficient time after harvest for the completion of two leafy flushes before winter most years. It may be that hedging two leafy flushes out from winter might improve the chance of flowering by giving the canopy a longer time to recover from hedging, but this idea needs to be tested.

The rate of shoot development in litchi is dependent on temperature and radiation (Olesen et al., 2002). Predicting the best time to prune to ensure two flushes out from winter is more difficult than predicting the best time to prune to ensure one flush out from winter. The model developed by Olesen et al. was based on average weather conditions at the various sites along eastern Australia. There is considerable variation in seasonal temperatures and radiation from year to year in this environment.

We also included a set of trees at Mareeba in 1995 where the branches were pruned in June when the trees would be expected to initiate inflorescences. This was a repeat of the experiment at Bundaberg in the same year. In the experiment at Mareeba, the hedged trees had only half the yield of the control trees, although the difference between the two treatments was not significant. This was possibly because we only used 4 trees in each group.

Even with the optimal hedging for a given site, measures to deal with late autumn flushes that inhibit floral initiation will be needed in some seasons because of variability in the weather from year to year. These techniques include the use of water deficits to suppress shoot development (Stern et al., 1998), and the use of chemicals to burn off the immature flushes or the use of light pruning to cut off the immature flushes (Menzel et al., 2000; Olesen et al., 2002).

\subsection{Pruning in other countries and environments}

Menzel (2005) reported that average yields of litchi in experimental plots in various countries ranged from 3.6 to $19.5 \mathrm{t}$ per ha. Productivity in this species is highly variable, but tends to be more regular in areas that have consistent cool periods around the normal time of floral initiation. In some growing areas such as Israel and South Africa, flowering is also more regular when dry weather limits the production of late vegetative flushes before winter. This does generally not occur in places such as Australia, Florida and Hawaii.

This paper provides suggestions for pruning under three different growing environments that are applicable to other production areas. In warm tropical areas, the trees can be pruned to produce one or two vegetative flushes before winter, but there is often a small window for successful floral initiation. In warm subtropical areas, there is a long window for floral initiation and the trees will flower most years if pruned a month or so after harvest. In cool subtropical areas, there is also a long window for floral initiation, but often the optimum time for pruning is before the trees are harvested. Pruning only part of an individual tree is probably the best option.

\section{Conclusions}

Hedging had mixed effects on the performance of litchi trees growing along eastern Australia. The best response occurred in southern Queensland where the fruit are harvested relatively early in January and there are 2-3 months of cool weather, which favours regular floral initiation. In this environment, the best time of pruning is from late February to early March. There is a problem with hedging the trees in the cooler environment of northern New South Wales in that the best time for pruning is in early February before the fruit are typically harvested. In the warmer environment of northern Queensland, there is a different scenario. There are probably optima for one or two flushes out from winter for regular flowering, but the trees may not flower every year because the generally warmer conditions provide only a short window for floral initiation. There is a problem with hedging the trees in winter 
because pruning removes the main part of the canopy that supports the developing crop.

\section{Acknowledgements}

We thank Robin Amos, Derek Foley and Barry Hartley for the use of the trees on their properties and for their generous support and hospitality. We also appreciate the financial support of the Rural Industries Research and Development Corporation (Australia) and the Australian Lychee Growers' Association.

\section{References}

Batten, D.J., McConchie, C.A., 1995. Floral induction in growing buds of lychee (Litchi chinensis) and mango (Mangifera indica). Aust. J. Plant Physiol. 22, 783-791.

Bikash, D., Jana, B.R., Dey, P., Nath, V., 2011. Assimilate partitioning behaviour in relation to fruit growth in 'Shahi' litchi. Int. J. Fruit Sci. 11, 88-98.

Borchert, R., 1969. Unusual shoot growth pattern in a tropical tree Oreopanax (Araliaceae). Am. J. Bot. 56, 1033-1041.

Borchert, R., 1991. Growth, periodicity and dormancy. In: Physiology of Trees. John Wiley \& Sons, New York, USA, pp. 221-245.

Campbell, R.J., 1994. Fall pruning induces blooming in young lychee trees. Proc. Fla. State Hortic. Soc. 107, 348-350.

Chaikiattiyos, S., Menzel, C.M., Rasmussen, T.S., 1994. Floral induction in tropical fruit trees: effects of temperature and water supply. J. Hortic. Sci. 69, 397-415.

Davenport, T.L., 2007. Reproductive physiology of mango. Braz. J. Plant Physiol. 19, 363-376.

Diczbalis, Y., Nicholls, B., Groves, I., Lake, K., 2010. Sapindaceae production and research in Australia. Acta Hortic. 863, 49-58.

Goren, M., 1990. High density litchi orchards. Alon Hanotea 44, 699-704.

Hieke, S., 2000. Physiology of leaf and fruit growth in lychee (Litchi chinensis Sonn.). Dissertation. Humboldt University, Berlin, Germany, 192 pp.

Hieke, S., Menzel, C.M., Doogan, V.J., Lüdders, P., 2002a. The relationship between fruit and leaf growth in lychee (Litchi chinensis Sonn.). J. Hortic. Sci. Biotechnol. $77,320-325$

Hieke, S., Menzel, C.M., Doogan, V.J., Lüdders, P., 2002b. The relationship between yield and assimilate supply in lychee (Litchi chinensis Sonn.). J. Hortic. Sci. Biotechnol. 77, 326-332.

Ireland, C., 2010. Experimental Statistics for Agriculture \& Horticulture. CABI, Wallingford, UK, 360 pp.

Lang, A.R.G., 1991. Application of some of Cauchy's theorems to estimation of surface areas of leaves, needles and branches of plants and light transmittance. Agric. For. Meteorol. 55, 191-212.

Menzel, C., 2001. The physiology of growth and cropping in lychee. Acta Hortic. 558, 175-184.
Menzel, C.M., 2005. Photosynthesis and productivity. In: Menzel, C.M., Waite, G.K. (Eds.), Litchi and Longan. Botany, Production and Uses. CABI, Wallingford, UK, pp. 153-182.

Menzel, C., Bagshaw, J., Campbell, T., Greer, N., Noller, J., Olesen, T., Waite, G., Kernot, I., Chapman, L., Rigden, P., 2002. Lychee Information Kit. Dept. Primary Indust., Queensl.

Menzel, C., Olesen, T., McConchie, C., Wiltshire, N., Diczbalis, Y., Wicks, C., 2000. Optimizing canopy management in lychee, longan and rambutan. RIRDC Publication No. 00/29. Rural Indust. Res. Develop. Corpor., Canberra, Australia, 92 pp.

Menzel, C.M., Simpson, D.R., Doogan, V.J., 1996. Preliminary observations on growth, flowering and yield of pruned lychee trees. J. S. Afr. Soc. Hortic. Sci. 6, 16-19.

Menzel, C.M., Waite, G.K., 2005. Litchi and Longan. Botany, Production and Uses. CABI, Wallingford, UK, 305 pp.

Olesen, T., 2005. The timing of flush development, affects the flowering of avocado (Persea americana) and macadamia (Macadamia integrifolia $\mathrm{x}$ tetraphylla). Aust. J. Agric. Res. 56, 723-729.

Olesen, T., Menzel, C.M., Wiltshire, N., McConchie, C.A., 2002. Flowering and shoot elongation of lychee in eastern Australia. Aust. J. Agric. Res. 53, 977-983.

Olesen, T., Robertson, D., Muldoon, S., Meyer, R., 2008. The role of carbohydrate reserves in evergreen tree development, with particular reference to macadamia. Sci. Hortic. 117, 73-77.

Ramírez, F., Davenport, T.L., 2010. Mango (Mangifera indica L.) flowering physiology. Sci. Hortic. 126, 65-72.

Roe, D.J., Menzel, C.M., Oosthuizen, J.H., Doogan, V.J., 1997. Effects of current assimilation and stored reserves on lychee fruit growth. J. Hortic. Sci. 72 397-405.

Stern, R.A., Goren, M., Gazit, S., 2005. The effect of shoot pruning during the fall and winter on lychee flowering and yield. Acta Hortic. 665, 331-335.

Stern, R.A., Meron, M., Naor, A., Wallach, R., Bravdo, B., Gazit, S., 1998. Effect of fall irrigation level in 'Mauritius' and 'Floridian' lychee on soil and plant water status, flowering intensity, and yield. J. Am. Soc. Hortic. Sci. 123, 150-155.

Wilkie, J.D., Sedgley, M., Olesen, T., 2008a. Regulation of floral initiation in horticultural trees. J. Exp. Bot. 59, 3215-3228.

Wilkie, J.D., Sedgley, M., Olesen, T., 2009. A model of vegetative flush development and its potential use managing macadamia (Macadamia integrifolia) tree canopies. Crop Pasture Sci. 60, 420-426.

Wilkie, J.D., Sedgley, M., Olesen, T., 2010. The timing of pruning affects flushing, flowering and yield of macadamia. Crop Pasture Sci. 61, 588-600.

Wilkie, J.D., Sedgley, M., Robertson, D., Olesen, T., 2008b. The timing of pruning affects flush development and flowering in 'Honey Gold' mango. Acta Hortic. $787,241-243$.

Yen, C.R., Tien, Y.J., 1985. Effect of pruning on the growth and yield of litchi. 1. Effect of harvest pruning on the flushing and flowering in varieties of different vigor. J. Chin. Soc. Hortic. Sci. 31, 40-43.

Young, T.W., 1977. Effect of branch girdling on the yield of severely pruned 'Brewster' lychee trees. Proc. Fla. State Hortic. Soc. 90, 251-253.

Yuan, R.C., Huang, H.B., 1988. Litchi fruit abscission: its pattern, effect of shading and relation to endogenous abscisic acid. Sci. Hortic. 36, 281-292. 